\title{
Review on the Role of Dairy Product Processing and Preservation in Food Security of Ethiopia
}

\author{
Miftahi Abajiha Abasimal $^{1} \quad$ Andulsemed Abanega Abdurahman $^{2} \quad$ Ahmed Mohammed Abacebsa $^{3}$ \\ 1.Department of Agricultural Economics and Agribusiness Management, College of Agriculture and Veterinary \\ Medicine, Jimma University, Jimma, Ethiopia \\ 2.Department of Agribusiness and Value chain management, School of Business and Economics, Ambo \\ University, Woliso campus, Woliso, Ethiopia \\ 3.Department of Natural resource management, College of Agriculture and Veterinary Medicine, Jimma \\ University, Jimma, Ethiopia
}

\begin{abstract}
Ethiopia holds large potential for dairy development, the sector is not developed to the expected level. The objectives of this paper were to provide organized information on different types of dairy product processing, preservation and the role of dairy product processing and preservation in food security in the country. Milk production systems can be classified into three based on their location: urban, pre-urban and rural milk production systems. Urban dairy production system is placed in cities and towns, with small or no access to grazing land and small feeding conditions which focus on the production and sale of fluid milk, using the available human and capital resources. Pre-urban milk production is developed around city areas. Another types of dairy production system is the rural dairy system, which includes pastoralist, agropastoral and mixed croplivestock producers, mainly in the highland areas. There are four main methods used to process milk that are suitable for small-scale operation: Cooling fresh milk to extend the shelf life by a day or two, or freezing it. Heating milk to destroy both contaminating micro-organisms and naturally occurring enzymes that change the flavor of milk. Making the milk acidic to slow down or food poisoning bacteria, Reducing the amount of water in milk products to slow down or prevent the growth of bacteria are some Examples. Also, dairy production used for human consumption and it has great role in food security of the country.
\end{abstract}

Keywords: Ethiopia, dairy production, food security

DOI: $10.7176 / F S Q M / 110-02$

Publication date:September $30^{\text {th }} 2021$

\section{INTRODUCTION}

Ethiopia has the largest livestock inventory in Africa with the estimated domestic animals' population of 52.13 million, 24.2 million sheep, 22.6 million goat, 2.5 million camel, 44.89 million poultry, 1.96 million horse, 0.37 million mules and 6.4 million donkeys. Among livestock production sector, dairy production is critical in Ethiopia where livestock and its products are important sources of food and income, however dairying has not been fully exploited and promoted in the country. Based on market orientation and land holding, milk production system in Ethiopia can be broadly categorized in to three systems such as rural milk production system, periurban milk production system and urban milk production system. Cattle have the largest contribution (81.2\%) of total national animal milk output followed by goat (7.9\%), camel $6.3 \%$ and sheep $4.6 \%$. From the national 3.3 billion of milk production in Ethiopia 32\% is allocated for calf consumption and wastage and $68 \%$ is allocated for human consumption (CSA, 2012). Considering the important prospective for smallholder income generation and employment opportunities from the high value dairy Products, the development of the dairy sector can contribute immensely to poverty alleviation and improved nutrition in the country (Ahmed, et.al., 2004).

Although the country holds large potential for dairy development, the sector is not developed to the expected level. The annual growth rate in milk production of 1.2 percent falls behind the annual human population growth estimated at 3 percent (International, 2007). Dairy processing plants are few in numbers, much of the milk produced by rural small holders is processed on farm using traditional technologies and milk processing is based on sour milk (Getachew, 2003). In adequate feed source in quality as well as in quantity, traditional type of production system and lack of capital by dairy producers, unimproved animal husbandry systems, inefficient and inadequate milk processing materials and methods, low milk production and supply to milk processing centers and poor marketing and market information systems are the major factors that hinder the dairy sector in Ethiopia (Yilma, et al.,2011).

Furthermore, there is no standard hygienic condition followed by producers during milk production. The hygienic conditions are different according to the production system. In most of the cases under smallholder condition, the common hygienic measures taken during milk production especially during milking are limited to letting the calf to suckle for few minutes and washing the udder before milking. The quality of the water used for cleaning purpose however, is not secured. Milk production under Ethiopian smallholder condition can generally be characterized as unhygienic (Zelalem, 2003). The handling and safety of milk and milk products is of great 
concern around the world, this is especially true in the developing country where production of milk and various dairy products takes place under unsanitary condition and poor production sale must consider the health of consumer (Almaze, et al., 2001).

Milk processing is usually designed to remove water from milk or reduce the moisture contain of the product (Azage, et al.,2001). Each household accumulates milk either from a single milk animal or large number of animal and that is processed in to different products such as; butter, cottage, cheese, whey and concentrated fermented milk. Much of the milk produced in Ethiopia by rural stallholder farmers are either sold and/or consumed as fresh milk, fermented milk and milk product such as butter, ghee, cottage type cheese where it is processed on farm using traditional technology. The informal (traditional) market has remained dominant in Ethiopia. The traditional processing and trade of dairy products, especially tradition soured butter, dominate the Ethiopian dairy sector and only 5 percent is marketed as liquid milk due to underdevelopment of infrastructures in rural areas (Hailemikael, 2019).

Therefore, this review provides organized information on different types of dairy product processing and preservation and the role of dairy product processing and preservation in food security of Ethiopia.

\section{LITERATURE REVIEW}

\subsection{Definitions and Concepts of food security}

The most widely recognized definition of food security is access by all people at all times to enough food for an active, healthy life (World Bank 1986). This implies accessibility and stability dimensions. Accessibility refers to the ability to either produce or purchase the needed basic foods. It includes a time factor, distinguishing chronic and transitory household food insecurity. Food security has strong links with issues of poverty, employment and income generation. For developing countries, where more than $70 \%$ of the population lives in rural areas and depends on agriculture for its livelihood, increasing food production and commercialization of agriculture are the cornerstones for increasing food security and economic development.

Food availability is said to be determined by the level of food supplies, i.e., subsistence production and market supplies from domestic production, food stocks and food imports. Access to food is referred to as the ability to express food needs (beyond subsistence production) as effective demand (Thomson and Metz 1997). The effects of intensified dairying in the Ethiopian highlands on food security (accessibility and stability dimensions) and food marketed surplus are examined in this study.

\subsection{Dairy Production System in Ethiopia}

In Ethiopia, dairying is practiced all over the country by a large number of small or medium or large-sized, subsistence or market-oriented farms. Cattle, camel and goats are the main livestock species that supply milk in Ethiopia, with cows contributing $81.2 \%$ of the total milk output (Getachew, 2003). In Ethiopia, urban and preurban areas are used about 300,000 exotic cows for milk production under improved management conditions (Azege, et al., 2013).

According to (Tsehay, 2011), Based on their location, milk production systems can be classified into three: urban, pre-urban and rural milk production systems. In general, urban dairy production system are placed in cities and towns, with small or no access to grazing land and small feeding conditions which focus on the production and sale of fluid milk, using the available human and capital resources. Urban dairy production system has a better access to inputs and services provided by the public and private sectors, and use intensive management compared to other systems (Azege, et al., 2013). Highly specialized, or businessmen owned farms, which are highly involved in urban dairy farming system of the country (Getachew, 2003). Due to urbanization around big cities like Addis Ababa, the population density is high and agricultural land is decrease. Pre-urban milk production is developed in these types of areas. Smallholder and commercial dairy farmers sectors in the proximity of Addis Ababa and other regional towns are included and owns the pre-urban milk system (Tsehay, 2011). The primary objective of pre-urban milk production is to generate income from milk sale and main source of feed is both homes produced or purchased hay. Pre-urban milk production have an access to grazing land, which produces part of the remaining feed in the form of crop (Azege, et al., 2013). According to (Ahmed, et al., 2004) another types of dairy production system is the rural dairy system, which includes pastoralist, agro pastoralist and mixed crop-livestock producers, mainly in the highland areas. The milk produced in rural dairy system is consumed for personal purpose and not market-oriented. The demand for milk by the family and its neighbors, the potential to produce milk in terms of group, and access to a close market is determinant for the level of extra milk (Getachew, 2003). Using traditional technologies, the extra milk is processed in to by-product such as butter, ghee, ayib and sour milk which are usually marketed after the households satisfy their needs through the informal market (Tsehay, 2011).

\subsection{Dairy Processing in Ethiopia}

Most of the year Ethiopia has a hot climate and unless the milk is cooled, during this condition the raw milk is 
mess up. However, in some part of the rural area the cooling systems are not practicable. Besides, there are things like poor handling, pollution, technology applied which has low level in the conservation of milk to expand its shelf life and lack of market which create losses in the post-harvest (Getachew, 2003).

In milk production, it is important and take in to consideration to clean up the store, the person who is involved in milking and the utensils used to collect and store milk. And also, essential to cleaning of the udder before milking (Azege, et al., 2013). For collecting, storing and processing milk, dairy farmers used different milk utensils (Yitaye, et al., 2009). More farmers in urban used plastic utensils about 83 percent and the remaining 17 percent used aluminium utensils. In addition, there are farmers in urban who used gourd and clay pot utensils $33 \%$ and $21 \%$ respectively (Yitaye, et al., 2009). Milking procedures and cleanness of the milking utensils are one of the major factors affecting the quality of dairy products. 94 percent of the farmers in urban and pre-urban milk production system are cleaned the udder before milking. But there are farmers which cleaned the udder before and after milking, $6.7 \%$ and 5\% urban and pre-urban farmers respectively.

However, mostly at the pre-urban farms the water used especially from rivers for cleaning was uncertain quality. Due to this, the cleaning of udder and milking utensils might at danger (Yitaye, et al., 2009). But, in the rural dairy system, it is not commonly practice to clean udder before milking. Across all the PLWs, the traditional home processing method is the dominant processing method and it processing fresh milk into fermented or sour milk, butter and local cheese (Ayib) (Azege, et al., 2013). This method is in general time consuming, verities of products was limited and less milk fat recovery turned into butter per unit of milk processed (Getachew, 2003). Due to the above reason, some farmers buy milk products such as butter and Ayib and usually sell all the fresh milk.

Farmers could not get the full value-added product from milk production unless the farmers produce varieties of products. This is one reason to comparatively low for urban dairy producers to processing milk in to different by products such as butter and cheese (Yitaye, et al., 2009). Furthermore, when we compare the proportion of involved in processing milk in to cottage cheese, the pre-urban producers were slightly higher than of urban producers. Lack of fire wood availability for processing milk into cottage cheese and whey is another reason for urban producers not practicing this processing. Economically, the processing of milk into byproducts using electric energy is favourable than the use of milk for household consumption.

\subsection{Types of Dairy processing \\ * Fermented milk (Itittuu)}

'Itittuu' is produced from whole milk. Due to small volume of daily milk produced, producers keep milk produced over 3 to 4 days until sufficient amount is accumulated, to process it into the aforementioned more shelf stable products. Depending on the volume of milk and season of the year, the mean shelf life of fermented milk was $1.56 \pm 0.47$ days in dry season and $2.95 \pm 0.51$ in wet seasons. Environmental temperature and seasons of the year affects the duration of the fermentation. For example, during dry season, since the environmental temperature is very hot, the fermentation process is fast (Amanuel,et all., 2018).

\section{* Butter making and preservation}

Fresh butter is processed and sold by adult females in the study area. Milk is collected and stored for 3-4 days in milk equipments or Okolee for churning. Storing of milk for such days allow as the milk soured and make 'Itittuu'or naturally fermented milk. To make butter, Abuubbii/Ro'oo is the only milk equipment used as a churner and churning is completely done by adult females in the study area. When sufficient amount of milk is accumulated (7-8 liters), it is transferred to Abuubbii/Ro'oo (Lagenaria siceraria); and churning was done on the lap (leg) until butter granules are formed. According to farmers' report the breakpoint, i.e., the point when butter grains start to form is detected by inserting a wooden plug and pulling out to release a few drops of milk and to check whether butter granules have formed or not (Amanuel,et all., 2018).

\section{* Cottage cheese (Ayib) making and utilization}

Dairy producers in the study area make Ayib from Arera/Amma Raasee. The Arera is placed on a clay pot and heated on slow fire at approximately $30^{\circ} \mathrm{C}$ to $40^{\circ} \mathrm{C}$ for about $25-30$ minutes. After cooling, the whey is drained off. It was reported that about a kilogram of cottage cheese could be obtained from an estimated 10-12 litres of buttermilk. Ayib made as such is not marketed but used for home consumption. The whey obtained is either used for consumption by the family members or given to calves, cats or dogs. According to the respondents, Ayib can be stayed for up to 3-4 days without spoiled, if well-handled during processing (Amanuel,et all., 2018).

\subsection{Milking and Preservation}

\section{* Cooling}

According to Peter (2008), cooling does not destroy bacteria or enzymes but it slows down their activity. Cooled raw milk keeps its quality for a few days before it is processed. Milk products such as yoghurt, cheese, butter and pasteurized milk are also cooled to ensure they have the required shelf life for distribution to shops and retail storage. At the smallest (micro-) scale of operation, a refrigerator set at $4-50 \mathrm{C}$ can be used to cool milk, but 
most dairy processors use a milk cooler or cold store to cool milk in bulk before it is processed. Finished products should be stored in a separate dispatch store at $40 \mathrm{C}+/-2 \mathrm{o} C$, or for frozen milk and ice cream, frozen in a freezer operating at below $-180 \mathrm{C}$.

\section{* Heating}

There are regulations in most countries that specify the time and temperature that milk should be heated to pasteurize it. Most specify that milk should be heated to $63 \mathrm{o} \mathrm{C}$ for 30 minutes. Higher temperatures and shorter times are used in larger commercial operations but the equipment needed to do this is more expensive (Peter, 2008).

\section{* Removing water}

Separating milk fat from the watery part of milk produces cream. This can be made as a product for sale, but care is needed because there is a greater risk of cream causing food poisoning. Production of cream is not recommended except by the most experienced small-scale dairies. When butter is prepared and stored correctly, it can have a shelf life of several months. 'Cottage' cheese or simple curd cheeses are relatively easy to make at a small scale, but hard cheeses require greater levels of investment, and more skill and expertise. It is recommended that market research is undertaken to find which types of cheese are popular before contemplating production, because in some areas the demand for hard cheese is small. Training in production should then be obtained from an experienced cheese-maker (Peter, 2008). Another process is boiling milk to evaporate water and produce a brownish gel that is eaten as a snack food or sweet. The product has a shelf life of a few weeks and may have ingredients such as sugar, colour, spices, fruits or nuts added to give a variety of products.

\subsection{Dairy production and food accessibility}

Dairy production enhances food availability directly and indirectly. It directly increases food supply by making livestock products available for consumption, if farmers can forego cash income from marketing these highvalue products. Animals are important sources of high-quality protein, minerals, vitamins and micronutrients, essential for balanced growth. Meat, milk and eggs provide 17 to $18 \%$ of the dietary protein in African diets (Winrock International 1992). Quality foods of animal origin enhance human growth and development, particularly of children in chronically mild to moderately malnourished populations, because they contain amino acids absent in cereals and essential to human health. In developed countries, animal products provide about $60 \%$ of the dietary protein, compared with $22 \%$ in developing countries. In developing countries, animal products are important in preventing malnutrition as they are concentrated sources of amino acids not found in vegetable proteins or frequently eaten staple foods. Animal products contribute $30 \%$ of total calories in developed countries and less than 10\% in developing countries (Sansoucy et al. 1995). Cash can be obtained from the regular sale of milk, eggs, butter, cheese and dung cakes and occasionally from the sale of live animals, wool, meat, hides and skins as well as from services such as draft power and transport. In the mixed farming system of the Ethiopian highlands, sales of livestock and livestock products account for $83 \%$ of the cash income per year. Dairy products account for over $50 \%$ and manure for $25 \%$ of the sale of livestock products (Gryseels 1988).

An important part of the income obtained from animal husbandry is spent on food, agricultural inputs and other family needs (Sansoucy et al. 1995). This is particularly important for pastoral households for whom the terms of trade between livestock and grain is a major indicator of food security. Livestock keepers also exchange high value commodities like meat, eggs or milk for cheaper and larger quantities of food, such as local cereals and vegetables (Bouis and Haddad 1990). The introduction of market-oriented livestock technology, especially dairying, is one of the principal means through which the welfare and food security in mixed crop-livestock systems, such as that of Ethiopia, can be improved. It has the potential to contribute to the accessibility and stability elements of food security, via increased output of livestock and non-livestock agricultural products and through employment and income generation that may assure access to food (Sansoucy et al. 1995).

\subsection{Dairy animals as a source of food and income}

A pastoral herd tends to have as many cows as possible to produce milk for human consumption. Cattle and camels are the two important species in the pastoral areas due to their ability to provide more milk to the family consumption, while sheep and goats have fewer acceptances. Most of the pastoralists keep cattle, sheep, goats, and camel principally for milk production as a mainstay of their diet (IPS, 2000). The proportional importance of livestock to household income differs from one culture to another and within production system. For instance, mixed crop livestock farmers have opportunities for obtaining income from a variety of sources, thus, income from livestock probably contributes a smaller proportion to their household food. In the Borana plateau, roughly $40 \%$ of gross revenue is derived from milk and the remainder from live animals and meat. Nearly all of the food and income for pastoralist is ultimately derived from livestock (Coppock, 1994).

Despite the lower absolute volume of dairy sales, income from dairy sale provided $37 \%$ of the annual income of poor pastoral households that are close to market, for the wealthy this was $22 \%$. The poor with few 
animals, to sale without endangering their herd capital, had no variable alternative to sell milk in order to get money. Compared to animal sales, dairy sale permits purchasing of quantities of grain that are more convenient to handle by the household (Coppock, 1994).

\subsection{The role of dairy marketing in economic development}

The informal market involves direct delivery of milk by farmers to individual consumers in immediate neighborhood and sales to travelling traders or individuals in nearby towns. In informal market, milk may pass from producers to consumers directly or it may pass through two or more market agents. Ethiopia is not known to export dairy products; however, some insignificant quantities of milk and butter are exported to a few countries. Butter is mainly exported to Djibouti and South Africa (targeting the Ethiopians in Diaspora), while milk is solely exported to Somalia from the South Eastern Region of the country. As indicated by small quantities of cream are exported to Djibouti from Dire Dawa. The choice of targeting either domestic or export markets in the process of smallholder commercialization is basically linked to the nature of the targeted commodities (SNV, 2006).

The country spent over 678.75 million birrs to import various products of milk from 2006-2010. Expenditure on powdered milk accounted for 79.6\%, followed by cream, 12.9\% and cheese 4.3\% (MoA, 2013). With Ethiopia already spending approximately $\$ 10$ million annually in foreign powdered milk imports, there is a huge opportunity for domestic UHT production to disrupt the current market. Investment size A \$10-11 million greenfield investment would create a UHT plant with the largest processing capacity in the Ethiopian market Capacity 10,000 liters/hour (80,000 liters/day, 24 million liters/year employment 500-600 employees estimated return IRR of $25-35 \%$ over 5 years (Gezu, et al., 2018).

\section{Conclusion}

Ethiopia has high potential in dairy sector which account annual growth rate in milk production of 1.2 percent falls behind the annual human population growth estimated at 3 percent. The production systems of dairy product can be classified into three: urban, pre-urban and rural milk production systems. Also, there are different dairy processing system during preparation of milk for consumption. These are Naturally fermented milk is the basis of diversified milk products such as butter, yoghurt, buttermilk and whey manufacturing. Cooling fresh milk to extend the shelf life by a day or two, or freezing it. Heating milk to destroy both contaminating microorganisms and naturally occurring enzymes that change the flavor of milk. Making the milk acidic to slow down or prevent the growth of spoilage bacteria or food poisoning bacteria, Reducing the amount of water in milk products to slow down or prevent the growth of bacteria. Therefore, dairy production and processing has great role in economic development and reduction in food insecurity in Ethiopia. So, the stake holder of this sector has to participate and improve the production and processing system of dairy production.

\section{References}

$>$ Ahmed, M.A.M., S. Ehui and Y. Assefa, 2004. Dairy development in Ethiopia. EPTD Discussion paper No. 123. International Food Policy Research Institute.

$>$ Almaze G, Foster HA, Holzapfel WH (2001) Filed Survey and Literature Review of Ethiopian Traditional Fermented Milk Products. International Journal of food microbiology, Ethiopia.

$>$ Amanuel, B., Tekalign, T., Lemma, F., and Ulfina G., 2018. Milk and milk products processing, preservation and utilization in Gimbi district, West Wollega zone, Ethiopia. Scientific Journal of Animal Science (2018) 7(5) 504-510.

$>$ Azage Tegegne, Tsehay Reda, Alemu M Hizakias K (2013) Milk Recording and Herd Registration in Ethiopia. Pastoralism and agro-pastoralism which way forward; proceedings of the 8th annual conference of the Ethiopian society of animal production (ESAP).24-26 august,2000. Addis Ababa, Ethiopia, pp. 90-104.

$>$ Bouis H. and Haddad L. 1990. Agricultural commercialization, nutrition, and the rural poor: A case study of Philippines farm households. Lynne Rienner Publishers. Boulder, Colorado, USA. 191 pp.

$>$ Coppock, D.L.,1994. The Boran Pleatue of Southern Ethiopia: Synthesis of Pastoral Research, Development and Change, 1980-91. ILCA systems study. No.5. ILCA, Addis Ababa, Ethiopia. p 393.

> CSA (Central Statistical Authority) (2012) Agricultural Sample Survey on Livestock and Livestock Production (Private Peasant Holding). Statistical bulletin No.532. Addis Ababa, Ethiopia, 2: 9-20.

$>$ Getachew, F., 2003. Milk and Dairy Products, Post-harvest Losses and Food Safety in Sub-Saharan Africa and the Near East. A Review of the Small Dairy Sector - Ethiopia.FAO Prevention of Food Losses Programme. FAO, Rome: Italy.

$>$ Gezu T, Zelalem Y. Dairy Trade in Ethiopia: Current Scenario and Way Forward-Review. Dairy and Vet Sci J. 2018; 8(1): 555728. DOI: 10.19080/JDVS.2018.08.555728.

> Gryseels G. 1988. Role of livestock on mixed smallholder farms in the Ethiopian highlands. A case study from the Baso and Worena woreda near Debre Berhan. PhD dissertation. Agricultural University, 
Wageningen, The Netherlands. 249 pp.

$>$ Hailemikael M., 2019. Review on Traditional Handling, Processing and Marketing of Milk and its Derivative in Ethiopia. Journal of Dairy \& Veterinary Sciences.

$>$ Henson S, Loader R, Swinbank A, Bredahl S (1999) The impacts of sanitary and phytosanitary measures on developing country exports of agricultural and food products. The World Bank and WTO, Geneva.

$>$ International, B.V., 2007. Livestock Development Master Plan Study. Phase I Report-Data Collection and Analysis. Volume 1 - Dairy.

$>$ IPS, 2000. (International Project Service). Resource potential assessment and project identification study of the Somalia Region: Socio-economics assessment. Investment office of the Somalia regional state. Research Report. Vol.III. Somalia, Ethiopia. 351p.

$>$ MoA, ILRI (2013) Dairy value chain vision and strategy for Ethiopia. Addis Ababa, Ethiopia: Ministry of Agriculture and International Livestock Research Institute.

$>$ Peter F. 2008. Practical Action. The Schumacher Centre for Technology and Development. Bourton-onDunsmore.

$>$ Sansoucy R., Jabbar M., Ehui S. and Fitzhugh H. 1995. Keynote paper: The contribution of livestock to food security and sustainable development. ILRI (International Livestock Research Institute), Addis Ababa, Ethiopia.

$>$ SNV (2006) Developing a Market Led Strategy for the Ethiopian Dairy Industry, by Technoserve Kenya, Nairobi, Kenya, p. 43.

$>$ Thomson A. and Metz M. 1997. Implications of economic policy for food security. A training manual. Prepared for the agricultural policy support service policy assistance division, FAO (Food and Agriculture Organization of the United Nations) and GTZ (Deutsche Gesellschaft fur Technische Zusammenarbeit). FAO, Rome, Italy.

$>$ Tsehay Redda, 2011. Small-scale milk marketing and processing in Ethiopia. Ministry of Agriculture, Addis Ababa, Ethiopia.

$>$ Winrock International. 1992. Assessment of animal agriculture in sub-Saharan Africa. Winrock International, Morrilton, Arkansas, USA. 125 pp.

$>$ World Bank. 1986. Poverty and hunger: Issues and options for food security in developing countries. A World Bank Policy Study. World Bank, Washington, DC, USA. 82 pp.

$>$ Yilma, Z., G.B. Emannuelle and S. Ameha, 2011.A Review of the Ethiopian Dairy Sector. Ed. Rudolf Fombad, Food and Agriculture Organization of the United Nations, Sub Regional Office for Eastern Africa (FAO/SFE), Addis Ababa, Ethiopia.

$>$ Yitaye Alemayehu, Wurzinger M, Azage Tegegne And W Zollitsch, 2009. Handling, Processing and Marketing of Milk in The North Western Ethiopian Highlands. Livestock Research for Rural Development. International Livestock Research Institute (ILRI), Addis Ababa, Ethiopia.

$>$ Zelalem, Y., 2003. Sanitary conditions and microbial qualities of dairy products in urban and peri-urban dairy shed of the central Ethiopia. LAMBERT Academic publishing. 